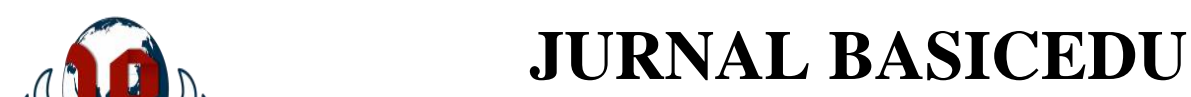

Volume 5 Nomor 3 Tahun 2021 Halaman 1547 - 1554

Research \& Learning in Elementary Education

https://jbasic.org/index.php/basicedu

\title{
Peningkatan Keterampilan Berpikir Kritis Siswa Melalui Model Problem Based Learning pada Siswa Sekolah Dasar
}

\author{
Arindra Ikhwan Nur Huda ${ }^{1 凶}$, Muhammad Abduh ${ }^{2}$ \\ Pendidikan Profesi Guru, FKIP, Universitas Muhammadiyah Surakarta, Indonesia ${ }^{1}$ \\ SD Negeri 3 Pandean, Kec Ngemplak, Kab Boyolali, Indonesia ${ }^{2}$ \\ E-mail : arindrahuda@gmail.com ${ }^{1}, \underline{\text { ma123@ums.ac.id }}^{2}$
}

\begin{abstract}
Abstrak
Penelitian ini di latar belakangi karena rendahnya pemahaman analisis berpikir kritis siswa pada muatan pembelajaran IPS. Hal tersebut karena pembelajaran selama pandemi yang digunakan guru kelas masih kurang bervariasi serta kurangnya menggunakan media pembelajaran. Siswa hanya mengerjakan buku lks tanpa penjelasan dalam pembelajaran. Akibatnya siswa dalam pembelajaran hingga hasil berpikir kritis siswa rendah. Tujuan penelitian ini untuk meningkatkan berpikir kritis siswa pada pembelajaran IPS dengan metode penelitian tindakan kelas. Metode yang digunakan pada penelitian dengan model Problem Based Learning. Penelitian dilaksanakan dengan dua siklus. Setiap siklus terdiri dari empat tahap kegiatan yaitu, perencanaan, tindakan, observasi, dan refleksi. Subjek penelitian adalah siswa kelas V SD Negeri 3 Pandean dengan jumlah 28 orang. data penelitian ini menggunakan tes. Berdasarkan penelitian menerapkan model PBL diperoleh hasil yang memuaskan. Hal ini dilihat dari rata-rata ketuntasan mengalami peningkatan. Pada siklus I rata-rata siswa $68,96 \%$ meningkat menjadi $85,36 \%$ pada siklus II. Selain itu aktivitas siswa juga mengalami peningkatan pada setiap siklusnya. Hal tersebut dapat disimpulkan bahwa pembelajaran IPS di SD dengan menerapkan model PBL dapat meningkatkan keterampilan berpikir kritis siswa.
\end{abstract}

Kata Kunci : Berpikir Kritis, IPS, Problem Based Learning, Kelas 5

\begin{abstract}
Abstrac
This study is backgrounded because of low understanding of critical thinking analysis of students on IPS learning content. This is because the learning during pandemic used by class teachers is still less varied and lack of use of media in learning. Students are only to work on lks without explanation and a concrete of learning. As result students understanding have difficulty until the results critical thinking students are low.The purpose of study is to improve critical thinking of students on content of IPS learning with class action research methods. Methods used in research with Problem Based Learning learning model. The research was conducted in two cycles. Each cycle consists four stages of activities, namely, planning, action, observation, and reflection. The subject of was grade V SDN 3 Pandean with a total of 28 people. Research using tests and observations. Based the results study applying in model PBL obtained satisfactory results. This is from the average completion has increased. In cycle average is $68.96 \%$ increased to $85.36 \%$ in cycle II. Students activities in learning process also increase in each cycle. It can be concluded that IPS learning in elementary school by applying PBL model can improve students critical thinking skills.
\end{abstract}

Keywords: Critical Thinking, IPS, Problem Based Learning, Grade 5.

Copyright (c) 2021 Arindra Ikhwan Nur H, Muhammad Abduh

Corresponding author :

Email : arindrahuda@gmail.com

DOI $\quad$ : https://doi.org/10.31004/basicedu.v5i3.973

ISSN 2580-3735 (Media Cetak)

ISSN 2580-1147 (Media Online)

Jurnal Basicedu Vol 5 No 3 Tahun 2021

p-ISSN 2580-3735 e-ISSN 2580-1147 
1548 Peningkatan Keterampilan Berpikir Kritis Siswa Melalui Model Problem Based Learning pada Siswa Sekolah Dasar - Arindra Ikhwan Nur H, Muhammad Abduh

DOI: https://doi.org/10.31004/basicedu.v5i3.973

\section{PENDAHULUAN}

Lampiran Permendikbud No 21 Tahun 2016 tentang standar isi, menyatakan muatan pembelajaran Ilmu Pengetahuan Sosial adalah bagian salah satu bagian muatan pembelajaran yang disampaikan pada Sekolah Dasar (SD). Salah satu tujuan kompetensi belajar siswa pada muatan pembelajaran IPS salah satunya kritis terhadap aktivitas dinamika manusia dalam kehidupan sosial, budaya, serta ekonomi. Selanjutnya mendalami hasil eksplorasi mengenai kehidupan bangsa Indonesia dengan berpikir kritis terhadap perubahannya. Sebagai wujud implementasi dalam eksplorasi serta mempelajari IPS pada materinya. Sejalan dengan pendapat tersebut diungkapkan oleh Rainbot dan Dwyer pada (Haryanti, 2017) bahwa berpikir kritis berarti keterampilan mengevaluasi argumen-argumen yang dibuat orang lain dengan benar dan membuat sendiri argumen yang baik dan benar. Oleh sebab itu maka dalam memeberikan pembelajaran IPS diharapkan guru mampu mengasah keterampilan berpikir kritis siswa, Pada lampiran Permendikbud No 21 Tahun 2016 pola pembelajaran menggunakan kurikulum 13 selain dapat memahami isi pengetahuan dan membentuk karakter siswa di harapkan dapat menumbuhkan kompetensi yang lainya seperti: Berpikir kritis dalam memecahkan masalah, dan menumbuhkan keaktifan dalam belajar sebagai pertimbangan guru dalam membimbing siswa lebih lanjut. Rumusan siswa pada kompetensi inti di antaranya yaitu menerima, menjalankan, serta dengan menghargai ajaran agama yang dianutnya.

Kurikulum 2013 saat ini didalamnya tidak hanya memuat tentang pengetahuan saja namun juga kegiatan yang membentuk keterampilan dengan mengasah sikap dengan menanamkan pembelajaran diikuti penanaman nilai atau pesan pada setiap kegiatan belajar sebagai upaya untuk digunakan dalam kehidupan sehari-hari. Menurut (Nawawi, 2020) kurikulum 2013 lebih menekankan peserta didik untuk berpikir secara kritis dalam mengidentifikasi, memahami, memecahkan masalah, dan mengaplikasikan materi pembelajaran, sehingga hasil akhirnya berupa peningkatan dan keseimbangan antara kemampuan untuk menjadi manusia yang baik (soft-skill) dan manusia yang memiliki kecakapan serta pengetahuan untuk hidup secara layak dari peserta didik meliputi aspek kompetensi sikap, keterampilan dan pengetahuan. Selain itu peningkatan berpikir kritis juga merupakan salah satu prioritas dalam pembelajaran di sekolah Muatan pembelajaran IPS kelas V pada kurikulum 2013 dengan membimbing siswa untuk memiliki kompetensi perilaku sosial dan budaya yang mencerminkan jati diri bangsa Indonesia serta menumbuhkan semangat siswa dalam menumbuhkan kreativitas pada kegiatan pembelajaran siswa di sekolah akan dapat mengikuti serta membiasakan untuk mempraktekkan di dalam kehidupan sehari-hari.

Hasil observasi dan wawancara yang dilakukan di SD Negeri 3 Pandean Kabupaten Boyolali di kelas V pada muatan pembelajaran IPS dalam melaksanakan pembelajaran dimassa pandemi ini masih terdapat beberapa kendala saat penerapan pembelajaran, guru mengungkapkan kendala tersebut diantaranya: (1) Ungkapan guru menyadari kurang maksimalnya dalam penguasaan ICT, metode TPACK (2) Kemudian, saat mengikuti pembelajaran siswa di dalam kelas cenderung pasif karena guru lebih dominan menjelasksan dan siswa selalu mendengarkan saja, (3) Kegiatan pembelajaran di masa pandemi guru lebih dominan untuk memberikan arahan mengerjakan modul dan LKS pada buku yang dibagikan, (4) Hasil belajar siswa saat ini masih banyak yang mendapat nilai di bawah KKM.

Dari 28 siswa-siswi hanya 11 siswa yang mencapai KKM, sedangkan 60\% sisanya masih belum mencapai KKM. sehingga beberapa hal tersebut mengakibatkan menurunnya hasil belajar siswa serta keterampilan berpikir kritisnya siswa. Kegiatan pelaksanaan pembelajaran tersebut membuat dampak terhadap siswa-siswa kelas V dampak yang dialami oleh siswa adalah siswa menjadi kurang bersemangat dalam mengikuti pembelajaran karena monoton kemudian kurangnya siswa dalam berpikir krits dan cenderung pasif dalam pembelajaran.

Setelah melakukan pengamatan, observasi belajar serta diperoleh data serta merencanakan, melaksanakan pembelajaran dengan membuat siswa untuk aktif serta meningkatkan hasil belajar dan 
1549 Peningkatan Keterampilan Berpikir Kritis Siswa Melalui Model Problem Based Learning pada Siswa Sekolah Dasar - Arindra Ikhwan Nur H, Muhammad Abduh

DOI: https://doi.org/10.31004/basicedu.v5i3.973

keterampilan berpikir kritis pada saat ini belum terlaksana dengan maksimal. Kemudian perlu di ciptakan suatu pembelajaran dengan muatan IPS memuat kondisi menarik, menyenangkan dan membuat siswa untuk berpatisipasi secara aktif serta mampu meningkatkan keterampilan berpikir kritis dan hasil belajar siswa adalah model pembelajaran Problem Based Learning (PBL) karena model pembelajaran tersebut dapat membangun keterampilan berpikir kritis siswa SD.

Keterampilan berpikir kritis menurut (Wulandari dkk, 2020) sangat penting dimiliki setiap orang, karena berpikir kritis merupakan sesuatu sangat esensial, dan berfungsi efektif dalam semua aspek kehidupan. Berpikir kritis sangat diperlukan bagi setiap manusia khususnya bagi siswa. Berikut adalah penjelasan mengapa berpikir kritis itu penting bagi siswa: 1) Berpikir kritis memungkinkan siswa untuk mengevaluasi bukti asumsi, logika, dan bahasa yang mendasari peryataan orang lain. 2) Berpikir kritis memungkinkan siswa menemukan kebenaran di tengah-tengah derasnya informasi yang mengelilingi mereka setiap hari. 3) Berpikir kritis akan memungkinkan siswa untuk mempelajari masalah secara sistematis, menghadapi berjuta tantangan dengan cara terorganisasi, merumuskan pertanyaan inovatif, dan merancang desain pembelajaran orisinal.

Desain Pembelajaran dengan menggunakan masalah salah satunya adalah penggunaan model pembelajaran kooperatif tipe Problem Based Learning. Problem Based Learning menurut Suharia dkk dalam (Rahayu dkk, 2019) menyatakan Problem Based Learning merupakan model pembelajaran yang menghadapkan siswa pada masalah dunia nyata dalam memulai pembelajaran. Hal tersebut dilakukan supaya siswa dapat memperoleh informasi dari lingkungan sekitar mereka berdasarkan pada permasalahan yang ada dalam kehidupan sehari-hari dan dengan tujuan siswa dapat memecahkan masalah dengan solusi berdasarkan scientific attitude. Pendapat lain sampaikan oleh Amin pada (Fitriyyah dkk, 2019) mengungkapkan model pembelajaran Problem Based Learning menggunakan masalah autentik (nyata) yang digunakan untuk memperoleh pengetahuan serta menentukan suatu keputusan yang dilakukan dengan cara memecahkan permasalahan tersebut serta berpikir kritis.

Berdasarkan pendapat para ahli, maka disimpulkan bahwa model pembelajaran Problem Based Learning adalah salah satu model pembelajaran yang mampu mengembangkan cara siswa dalam belajar aktif dengan menemukan sendiri, menyelidiki dalam memecahkan masalah serta melatih siswa dalam bertanggungjawab salam permasalahannya dalam pelaksanaannya berpusat pada siswa dimana kelompokkelompok siswa dibawa kedalam suatu persoalan untuk mencari jawaban dengan menekankan kepada pentingnya pemahaman struktur, atau ide-ide yang penting terhadap suatu disiplin ilmu melalui keterlibatan siswa secara aktif dalam kegiatan pembelajaran.

Menurut sumartini (Widayanti dkk, 2020) mengemukakan bahwa karakteristik dari pembelajaran berbasis masalah (Problem Based Learning) adalah (1) berdasarkan masalah, masalah membantu pengembangan kemampuan sendiri bukan menguji kemampuan, (2) masalahnya benar-benar ill structured, tidak setuju pada sebuah solusi, dan ketika informasi baru muncul dalam proses, presepsi akan masalah dan solusi pun dapat berubah, (3) guru bertindak sebagai pelatih dan fasilitator, siswa menyelesaikan masalahnya sendiri, (4) tidak ada suatu rumus bagi siswa untuk menyelesaikan masalah, siswa hanya diberikan petunjuk bagaimana mendekati masalah, dan (5) orisinalitas dan penampilan. Dalam penerapan model pembelajaran Problem Based Learning terdiri dari 5 langkah utama. Hosnan dalam (Dirgatama dkk, 2016): 1) Orientasi siswa pada masalah. 2) Mengorganisasikan siswa untuk belajar. 3) Membimbing penyelidikan individual dan kelompok. 4) Mengembangkan dan menyajikan hasil karya. 5) Menganalisis dan mengevaluasi proses pemecahan masalah Kegiatan.

Beberapa penelitian menunjukkan peningkatan keterampilan berpikir kritis dengan menggunakan model pembelajaran Problem Based Learning. Diantaranya oleh Sugi Oktari pada (Pramudya, Kristin and Anugraheni, 2019) pada penelitian yang dilakukan pada siklus I keberhasilan siswa $71 \%$ dan siklus II meningkat menjadi 83\% dengan model pembelajaran Problem Based Learning. Sejalan pada penelitian yang tersebut, (Ulandari dkk, 2020) mengungkapkan hasil penelitian tentang peningkatan berpikir krits melalui 
metode Problem Based Learning siswa kelas IV memperoleh hasil Pada siklus I kemampuan berpikir kritis siswa rata-rata 67,5 dan pada siklus II kemampuan berpikir kritis siswa rata- rata 92. Dari hasil penelitian ini bahwa pembelajaran IPA dengan menggunakan metode Problem Based Learning pada materi gaya berhasil diterapkan dan dapat meningkatkan kemampuan berpikir kritis siswa. Jadi dapat disimpulkan bahwa terjadi peningkatan hasil belajar siswa dari 57,5\% menjadi 95\%. Penelitian lain juga dilakukan oleh (Ayuningsih dkk, 2019) penerapan model pembelajaran PBL pada siswa kelas 5 SDN 1 Ngambakrejo. Hal tersebut dibuktikan dengan peningkatan pada kemampuan berpikir kritis siswa, yaitu pada tahap siklus I nilai rata-rata 62,3. Selanjutnya pada siklus II mengalami peningkatan nilai rata-rata menjadi 77. Pada hasil belajar siswa juga terjadi peningkatan, hal tersebut ditunjukan dariketuntasan hasil belajarsiswapada tahap siklus I sebanyak 11 siswa dengan persentase 40,7 dan semakin meningkat pada siklus II menjadi 19 siswa dengan persentase 70,3.

Berdasarkan permasalahan observasi pada SD Negeri 3 Pandean, dapat diasumsikan bahwa pembelajaran yang dilakukan belum maksimal. Perlu adanya perbaikan pembelajaran yang tepat untuk meningkatkan keterampilan berpikir kritis siswa. Solusi untuk meningkatkan masalah tersebut yaitu dengan menggunakan model pembelajaran yang inovatif. Model pembelajaran Problem Based Learning (PBL) adalah model pembelajaran yang di dalam proses pembelajaran menggunakan masalah.dalam mencapai tujuan penelitian yang akan dibahas oleh peneliti maka disusun hipotesis tindakan pada penelitian ini adalah: 1) mendeskripsikan bagaimana langkah-langkah penerapan model pembelajaran Problem Based Learning dapat meningkatkan keterampilan berpikir kritis pada siswa kelas V SDN 03 Pandean Kabupaten Boyolali. 2) meningkatkan keterampilan berpikir kritis pada pembelajaran IPS dengan menggunakan model pembelajaran Problem Based Learning siswa kelas V SDN 03 Pandean Kabupaten Boyolali.

\section{METODE}

Peneliti dalam melaksanakan penelitian termasuk jenis penelitian tindakan kelas. Menurut (Linggayani Sinulingga, 2020) pengertian Penelitian Tindakan Kelas (PTK) atau Classroom Action Research adalah penelitian praktis yang dimaksudkan untuk memperbaiki pembelajaran di kelas. Penelitian ini merupakan salah satu upaya guru atau praktisi dalam bentuk berbagai kegiatan yang dilakukan untuk memperbaiki dan atau meningkatkan mutu pembelajaran dikelas. Penelitian tindakan kelas merupakan strategi terstruktur berupa rencana sistematis yang terdokumentasi sehingga dapat membantu guru untuk terus berinovasi terhadap segala permasalahan di kelas ungkap Ameliasari (Daswita, 2021). Kemudian pendapat berbeda mengungkapkan, PTK merupakan kegiatan untuk mengamati kejadian dalam pembelajaran di kelas guna memperbaiki hasil belajar menjadi lebih baik dalam proses pembelajaran ungkap Bahri pada (Hartono, 2009). Pelaksanaan penelitian ini dilakukan dengan beberapa siklus, serta dengan menggunakan model spiral sesuai dengan yang dikemukakan oleh Kemmis dan Targat dalam (Hendawati dkk, 2017) yang terdiri dari perencanaan, observasi $\&$ tindakan serta refleksi. Prosedur pada setiap siklus saling berkesinambungan.

Bagan 1. Model Spiral Oleh Kemmis dan Targgat

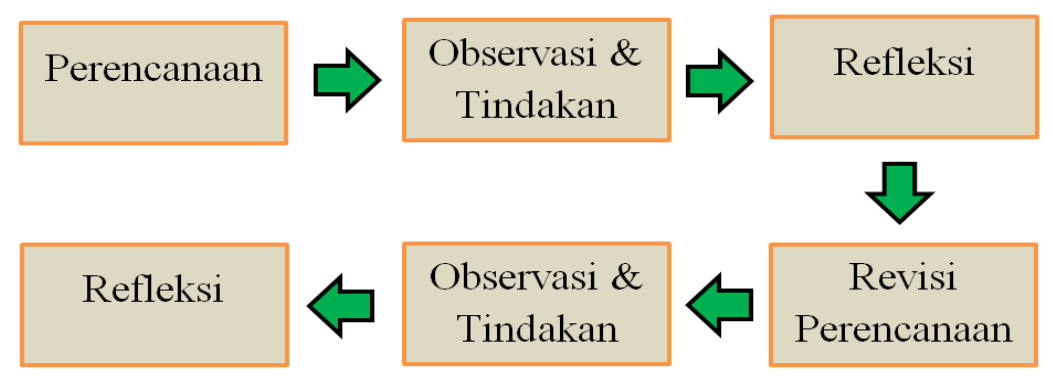


Pelaksanaan penelitian di SD Negeri 3 Pandena semester 2 tahun ajaran 2020/2021. SD Negeri 3 Pandean merupakan SD yang terletak di dusun Pandean, Kecamatan Ngempak, Kabupaten Boyolali. Kemudian subjek penelitian ini merupakan siswa kelas 5 SD Negeri 3 Pandean berjumlah 28 siswa. Pelaksanaan penelitian ini bekerjasama dengan guru kelas 5 SD Negeri 3 Pandean yaitu Ibu Sukemi, S.Pd dalam melaksanakan penelitian ini.

Penelitian saat pengumpulan data pelaksanaannya menggunakan teknik tes. Teknik tes berupa rubrik penilaian untuk mengukur tingkat keterampilan berpikir kritis siswa. Peneliti pada indikator penilaian yang telah disesuaikan dengan materi serta karakteristik siswa. Sistem penilaian yang digunakan pada rubrik penilaian ini ialah setiap 1 item soal mendapat skor maksimal 4 poin. Adapun skor maksimal total rubrik ialah 100 poin. Rubrik pada penelitian ini telah dilakukan uji validitas menggunakan SPSS versi 23. Sedangkan untuk teknik non tes menggunakan lembar observasi guru dan siswa. Isi pada kegiatan non tes tersebut berupa lembar observasi pembelajaran IPS dengan menggunakan prosedur model pembelajaran Problem Based Learning. Pengisisan lembar observasi tersebut dilakukan saat pembelajaran dimulai hingga di akhir

Teknik analisis data yang digunakan pada penelitian ini merupakan teknik kuantitatif dan teknik komparatif. Pada indikator yang sudah ditetapkan peneliti melakukan perbandingan ketika tindakan pra siklus, Siklus I dan, Siklus II. Pada penelitian ini ditetapkan untuk keberhasilan ditandai dengan adanya peningkatan keterampilan berpikir kritis siswa menggunakan model pembelajaran Problem Based Learning kemudian setelah diterapkan model pembelajaran Problem Based Learning keterampilan berpikir kritis meningkat apabila rata-rata kelas mencapai lebih dari nilai 80 serta presentase siswa mencapai KKM lebih dari $75 \%$.

\section{HASIL DAN PEMBAHASAN}

Penelitian yang dilaksanakan di SD Negeri 3 Pandean terdapat 2 siklus. Pada setiap siklus dilakukan 2 kali pertemuan, pada 1 kali pertemuan menggunakan alokasi waktu 3 x 35 menit pembelajaran. Selanjutnya tabel dibawah ini merupakan hasil perbandingan peneleitian keterampilan berpikir kritis pada muatan pembelajaran IPS menggunakan model pembelajaran Problem Based Learning kelas 5.

Tabel 1. Perbadningan hasil Keterampilan Berpikir Kritis siswa

\begin{tabular}{|l|l|c|c|c|c|c|c|}
\hline \multirow{2}{*}{ No } & Kategori Keterampilan & \multicolumn{2}{|c|}{ Pra Siklus } & \multicolumn{2}{c|}{ Siklus I } & \multicolumn{2}{c|}{ Siklus II } \\
\cline { 3 - 8 } & Berpikir Kritis & F & \% & F & \% & F & $\%$ \\
\hline 1 & Sangat Kritis & 0 & $0 \%$ & 1 & $4 \%$ & 9 & $32 \%$ \\
\hline 2 & Kritis & 10 & $36 \%$ & 11 & $39 \%$ & 18 & $64 \%$ \\
\hline 3 & Cukup Kritis & 3 & $11 \%$ & 8 & $29 \%$ & 1 & $4 \%$ \\
\hline 4 & Tidak Kritis & 12 & $43 \%$ & 7 & $25 \%$ & 0 & $0 \%$ \\
\hline 5 & Sangat Tidak Kritis & 3 & $11 \%$ & 1 & $4 \%$ & 0 & $0 \%$ \\
\hline
\end{tabular}

Pada tabel 1 diatas diketahui bahwa perbandingan nilai keterampilan berpikir kritis siswa. Pada pra siklus diketahui dari keseluruhan 28 siswa yang mendapat kategori "Sangat Kritis" sebanyak 0 siswa kemudian pada hasil "kritis" sebanyak 10 siswa dengan presentase $36 \%$. Selanjutnya pada kategori "cukup kritis" terdapat 3 siswa dengan presentase 11\%. Kemudian pada "tidak kritis" terdapat 12 siswa dengan presentase $43 \%$ dan pada kategori "sangat tidak kritis" terdapat 3 siswa dengan presentase $11 \%$. Setelah dilaksanakan siklus I pada kategori "Sangat Kritis" sebanyak 1 siswa dengan presentase 4\% kemudian pada hasil "kritis" sebanyak 11 siswa dengan presentase 39\%. Selanjutnya pada kategori "cukup kritis" terdapat 8 siswa dengan presentase 29\%. Kemudian pada "tidak kritis" terdapat 7 siswa dengan presentase $25 \%$ dan pada kategori "sangat tidak kritis" terdapat 1 siswa dengan presentase 4\%. Setelah melaksanakan siklus II diketahui hasilnya mendapat kategori "Sangat Kritis" sebanyak 9 siswa dengan presentase $32 \%$ kemudian pada hasil "kritis" sebanyak 18 siswa dengan presentase 64\%. Selanjutnya pada kategori "cukup kritis" terdapat 1 siswa 
dengan presentase $4 \%$. Kemudian pada "tidak kritis" terdapat 0 siswa dengan presentase $0 \%$ dan pada kategori "sangat tidak kritis" terdapat 0 siswa dengan presentase $0 \%$.

Tabel 2 Skor Keterampilan Berpikir Kritis Pada Pra Siklus, Siklus I, dan Siklus II

\begin{tabular}{|c|l|c|c|c|}
\hline No & & Pra Siklus & Siklus I & Siklus II \\
\hline 1 & Skor Terendah & 44 & 47 & 68 \\
\hline 2 & Skor Tertinggi & 81 & 91 & 94 \\
\hline 3 & Rata-Rata & 53,7 & 68,96 & 85,36 \\
\hline 4 & Kategori & Tidak Kritis & Cukup Kritis & Sangat Kritis \\
\hline
\end{tabular}

Pada tabel diatas diketahui bahwa pada setiap skor hingga kategori, skor keterampilan berpikir kritis siswa selalu meningkat, salah satunya pada rata-rata skor, saat dilakukan tindakan siklus I skor siswa meningkat menjadi 68,96, kemudian siklus II mengalami peningkatan menjadi 85,36. Hal tersebut terjadi saat diterapkan model pembelajaran Problem Based Learning skor siswa pada kategori terendah sebelum dilakukannya tindakan adalah 44 dan skor tertingginya 81, kemudian setelah dilakukannya tindakan siklus I skor terendah siswa menjadi 47 kemudian skor tertinggi siswa meningkat menjadi 91, kemudian saat dilakukan tindakan siklus II skor keterampilan berpikir kritis siswa yang terendah meningkat menjadi 68 serta skor tertingginya meningkat menjadi 94.

Pada penelitian ini juga di dukung dengan penelitian lain, salah satunya penelitian yang dilakukan oleh (Maulida dkk, 2020) melakukan penelitian dengan menerapkan model pembelajaran Problem Based Learning untuk meningkatkan keterampilan berpikir kritis dan sikap kerjasama di sekolah dasar yang memperoleh hasil meningkat dengan hasil dari penelitian ini menunjukkan bahwa kemampuan berpikir kritis pada siklus I memperoleh skor rata-rata 3,0 dengan kriteria cukup baik dan siklus II mengalami peningkatan memperoleh nilai rata-rata 3,6 dengan kriteria baik. Kemudian pendapat lain diungkapkan oleh (Haryanti, 2017) pada penerapan model pembelajaran Problem Based Learning untuk meningkatkan berpikir kritis siswa dengan hasil penelitian terjadi peningkatan kemampuan berpikir kritis siswa secara signifikan yaitu dari nilai rata-rata siswa 79 pada siklus I dan meningkat menjadi 85 pada siklus ke II.

Persentase ketuntasan adalah $77,7 \%$ pada siklus I dan meningkat menjadi $91,7 \%$ pada siklus II. Sejalan dengan pendapat tersebut Mawardi pada (Aini dkk, 2018) mengungkapkan model pembelajaran tersebut dapat mencapai tujuan pembelajaran. Hal tersebut juga sesuai dengan hasil penelitian dengan melakasanan tes keterampilan berpikir kritis yang memperoleh hasil pada pra siklus nilai rata-rata siswa sebesar 53,7 dengan kategori "tidak kritis", kemudian dilakukan tindakan siklus I rata-rata nilai siswa meningkat dengat rata-rata 68,96 dengan kategori "Cukup kritis". Setelah pelaksanaan siklus II diketahui hasil yang diperoleh rata-rata 85,36. Kemudian pada penelitian tersebut diketahui masih terdapat beberapa hal yang perlu di evaluasi. Kemudian keterbatasan temuan yang diperoleh salah satunya pelaksanaan pembelajaran yang masih menggunakan kelompok belajar, sehingga pembelajaran di sekolah masih terbagai-bagi dan diberikan batas dalam melaksanakan pembelajaran, kemudian keterbatasan dalam penelitian lainnya adalah perlunya guru untuk menyiapkan media pembelajaran yang inovatif serta dapat memuat karakteristik pembelajaran secara fisik, audiovisual dan kinestetik supaya siswa yang memliki karakteristik beragam dapat mengikuti pembelajaran lebih semangat kemudian pelaksanaan penelitian ini memiliki keterbatasn pada proses pengumpulan hasil aktivitas belajar siswa, akibat pandemic saat ini kegiatan pembelajaran di sekolah diberikan batas hingga pengerjaan evaluasi berpikir kritis dikerjakan di rumah.

\section{KESIMPULAN}

Berdasarkan hasil penelitian yang sudah dilaksanakan dapat disimpulkan bahwa: 1) Model pembelajaran Problem Based Learning dengan langkah-langkah: Mengarahkan pada masalah, Mengarahkan siswa pada 
1553 Peningkatan Keterampilan Berpikir Kritis Siswa Melalui Model Problem Based Learning pada Siswa Sekolah Dasar - Arindra Ikhwan Nur H, Muhammad Abduh

DOI: https://doi.org/10.31004/basicedu.v5i3.973

materi, Membimbing penyelidikan berkelompok, Mengarahkan siswa dalam menyajikan karya, Menganalisis serta evaluasi proses pemecahan masalah dapat meningkatkan keterampilan berpikir kritis siswa pada muatan pembelajaran IPS kelas 5 SD Negeri 3 Pandean, kemudian 2) hasil penelitian diketahui bahwa adanya peningkatan terhadap keterampilan berpikir kritis siswa, hal tersebut dibuktikan dengan sebelum dilakukan tindakan siswa mendapat rata-rata skor keterampilan berpikir kritis hanya 53,7 dengan skor terendah 47 kemudian skor tertinggi 81 kemudian hal tersebut masuk kedalam kategori "Tidak Kritis", kemudian setelah dilaksanakan tindakan siklus I diketahui adanya peningkatan skor keterampilan berpikir kritis siswa pada rataratanya mendapat 68,96 serta skor tertinggi siswa diketahui 91 dan skor terendahnya 47 hal tersebut menjadikan kategori siswa masuk "Cukup Kritis". Setelah itu dilanjutkan tindakan siklus II diketahui hasil yang diperoleh rata-rata siswa meningkat menajdi 85,36 kemudian skor tertinggi siswa diperoleh 94 hingga skor terendahnya mendapat skor 68 kemudian hal tersebut diketahui rata-rata siswa masuk pada kategori "Sangat Kritis". Demikian dapat disimpulkan bahwa model pembelajaran Problem Based Learning dapat meningkatkan keterampilan berpikir kritis siswa kelas 5 SD Negeri 3 Pandean Kab Boyolali pada muatan pembelajaran IPS semester 2 Tahun ajaran 2020/2021.

\section{UCAPAN TERIMAKASIH}

Penulis dalam menyusun penelitian ini mengucapkan puji syukur kepada Allah SWT atas limpahan rahmat dan hidayah dalam menyusun penelitian ini. Peneliti mengucapkan kepada kedua orang tua, istri tercinta beserta keluarga yang telah memberikan dukungan secara moral dan materil. Terimakasih kepada Bapak/Ibu Dosen Pendidikan Profesi Guru Universitas Muhammadiyah Surakarta dan teman-teman PPL serta guru dan staf SD Negeri 3 Pandean yang telah memberikan bimbingan dan arahannya. Semoga penelitian yang disusun dapat bermanfaat bagi semua. Serta pihak yang telah memberikan dukungan dalam peneliti.

\section{DAFTAR PUSTAKA}

Aini, Q. and Relmasira, S. C. (2018) 'Penerapan Pembelajaran Tematik Integratif Berbasis Kontekstual untuk Meningkatkan Keaktifan dan Hasil Belajar Siswa Kelas 1 SD', Sekolah Dasar: Kajian Teori dan Praktik Pendidikan, 27(2), pp. 124-132. doi: 10.17977/um009v27i22018p124.

Ayuningsih, D., Kristin, F. and Anugraheni, I. (2019) 'Penerapan Model Pembelajaran Problem Based Learning (Pbl) Untuk Meningkatkan Hasil Belajar Dan Berpikir Kritis Matematika', Jurnal Cakrawala Pendas, 5(2), pp. 94-99. doi: 10.31949/jcp.v5i2.1351.

Dirgatama, C. H. A., Th, D. S. and Ninghardjanti, P. (2016) 'Penerapan Model Pembelajaran Problem Based Learning Dengan Mengimplementasi Program Microsoft Excel Untuk Meningkatkan Keaktifan Dan Hasil Belajar Mata Pelajaran Administrasi Kepegawaian Di Smk Negeri 1 Surakarta', Jurnal Informasi dan Komunikasi Administrasi Perkantoran, 1(1), pp. 36-53. Available at: https://jurnal.uns.ac.id/JIKAP/article/view/19138.

Fitriyyah, S. J., Sri, T. and Wulandari, H. (2019) 'Pengaruh Model Pembelajaran Problem Based Learning terhadap Berpikir Kritis Siswa SMP pada Pembelajaran Biologi Materi Pemanasan Global', BIOEDUKASI (Jurnal Pendidikan Biologi), 12(1), pp. 1-7.

Hartono (2009) 'Langkah-langkah Penelitian Tindakan Kelas', pp. 1-24.

Haryanti, Y. D. (2017) 'Model Problem Based Learning Membangun Kemampuan Berpikir Kritis Siswa Sekolah Dasar', Jurnal Cakrawala Pendas, 3(2). doi: 10.31949/jcp.v3i2.596.

Hendawati, Y. and Kurniati, C. (2017) 'Penerapan Metode Eksperimen Terhadap Pemahaman Konsep Siswa Kelas V Pada Materi Gaya Dan Pemanfatannya’, Metodik Didaktik, 13(1). doi: 10.17509/md.v13i1.7689. 
1554 Peningkatan Keterampilan Berpikir Kritis Siswa Melalui Model Problem Based Learning pada Siswa Sekolah Dasar - Arindra Ikhwan Nur H, Muhammad Abduh

DOI: https://doi.org/10.31004/basicedu.v5i3.973

In, M., Mipa, C. X. and Negeri, S. M. A. (2021) 'MENARA Ilmu Vol. XV No.01 April 2021', XV(01), pp. $18-31$.

Maulida, Y. N., Eka, K. I. and Wiarsih, C. (2020) 'Penerapan Model Problem Based Learning untuk Meningkatkan Kemampuan Berpikir Kritis dan Sikap Kerjasama di Sekolah Dasar', MUKADIMAH: Jurnal Pendidikan, Sejarah, dan Ilmu-ilmu Sosial, 4(1), pp. 16-21. doi: 10.30743/mkd.v4i1.1521.

Meningkatkan, U. et al. (2020) 'Jurnal Pendidikan Pengajaran', 1(3), pp. 217-238.

Pramudya, E., Kristin, F. and Anugraheni, I. (2019) 'Peningkatan Keaktifan Dan Hasil Belajar Ipa Pada Pembelajaran Tematik Menggunakan Pbl', NATURALISTIC: Jurnal Kajian Penelitian Pendidikan dan Pembelajaran, 3(2), pp. 320-329. doi: 10.35568/naturalistic.v3i2.391.

Rahayu, R. and Ismawati, R. (2019) 'Pembelajaran Berbasis Masalah Pada Materi Pencemaran Lingkungan Sebagai Upaya Melatih Kemampuan Pemecahan Masalah Pada Siswa Smk', Indonesian Journal of Natural Science Education (IJNSE), 2(2), pp. 221-226. doi: 10.31002/nse.v2i2.706.

Ulandari, W., Perdiansyah, F. and Zamroni, M. (2020) 'Peningkatan Berpikir Kritis Melalui Metode Problem Based Learning Siswa Kelas Iv Sdn Pinang 6 Tangerang', Indonesian Journal of Elementary Education (IJOEE), 1(2), pp. 42-51. doi: 10.31000/ijoee.v1i2.2930.

Widayanti, R. and Dwi Nur'aini, K. (2020) 'Penerapan Model Pembelajaran Problem Based Learning untuk Meningkatkan Prestasi Belajar Matematika dan Aktivitas Siswa', Mathema: Jurnal Pendidikan Matematika, 2(1), p. 12. doi: 10.33365/jm.v2i1.480.

Wulandari, R., Wardhani, S. and Nawawi, S. (2020) 'Pengaruh Model Problem Based LearningTerhadap Keterampilan Berpikir Kritis Siswa Materi Keanekaragaman Hayati’, 